\title{
PENGGUNAAN FLOW CHART UNTUK MENINGKATKAN KETERAMPILAN MENULIS NARASI SISWA KELAS VIII SMP N 25 PURWOREJO
}

\author{
Rina Tri Indrianingrum \\ SMA Negeri 2 Kebumen \\ rinatrii@ymail.com
}

\begin{abstract}
Abstrak: Penelitian ini bertujuan untuk mengetahui peningkatan keterampilan menulis narasi siswa kelas VIII SMP N 25 Purworejo dengan menggunakan media flow chart. Metode penelitian yang dipergunakan adalah penelitian tindakan kelas atau classroom action research. Hasil penelitian sebagai berikut: (1) Dari empat puluh siswa yang mengikuti praktik mengarang narasi dengan pendekatan proses dan media flow chart, 40 siswa mengalami kenaikan skor. (2) Sebelum diberi tindakan kemampuan menulis siswa sangat kurang dengan rata-rata skor karangan narasi siswa 56,45 dengan skor terendah 34 dan skor tertinggi 70. Setelah diberi tindakan, yaitu pada siklus pertama, kemampuan menulis siswa cukup meningkat dengan rata-rata skor karangan narasi siswa adalah 64,68 dengan skor terendah 60 dan skor tertinggi 75. Sementara itu, setelah diberi tindakan kedua, yaitu pada siklus kedua, kemampuan menulis siswa lebih meningkat dengan rata-rata skor karangan narasi adalah 77, 38 dengan skor terendah 70 dan skor tertinggi sebesar 82. Dan setelah diberi tindakan ketiga, yaitu pada siklus ketiga, kemampuan menulis siswa meningkat lagi dengan rata-rata skor karangan narasi adalah 81, 65 dengan skor terendah 71 dan skor tertinggi sebesar 85 .
\end{abstract}

Kata kunci: flow chart, menulis narasi.

\section{THE USE OR IMPLEMENTATION OF FLOW CHART TO IMPROVE NARRATIVE ESSAY WRITING SKILLS OF THE EIGHT GRADE STUDENTS AT SMP N 25 PURWOREJO}

\begin{abstract}
This study aims to determine the improvement of writing skills of the eight grade students at SMPN 25 Purworejo through flow chart media. The research applied Classroom Action Research (CAR). The results of the conducted study are as follows: (1) Among the forty students who followed the practice of composing narratives essay by using approach process and flow chart media, 40 students got higher scores than before. (2) Before being given the action, the students' writing ability is still low with an average score 56.45. It is showed by 34 as the lowest and 70 as the highest score. After being given the action, in the first cycle, students' writing ability is quite increased. It's seen by the students' score of narrative essays from the number 64.68 in average, 60 as the lowest score and 75 as the highest score. Meanwhile, in the second cycle of the action, students' writing ability was further increased with an average narrative essay score of 77.38 with the lowest score of 70 and the highest score of 82 . After being given the third cycle of the action, students' writing ability increased significantly with an average narrative essays score of 81.65 with 71 as the lowest score and 85 as the highest score.

Keywords: flow chart, narrative writing
\end{abstract}

\section{PENDAHULUAN}

Berdasarkan pengamatan peneliti, pembelajaran keterampilan menulis narasi di SMP N 25 Purworejo pada umumnya lebih banyak disajikan dalam bentuk teori-teori. Hal ini menyebabkan kurangnya kebiasaan menulis narasi oleh siswa sehingga mereka sulit menuangkan ide-idenya dalam bentuk tulisan narasi. Kurangnya praktik menulis narasi itulah yang menjadi salah satu faktor kurang terampilnya siswa dalam menulis narasi. Siswa Sekolah Menengah Pertama seharusnya dituntut untuk mampu mengekspresikan gagasan, pikiran dan perasaannya secara tertulis. Namun pada kenyataannya, kegiatan menulis belum dapat terlaksana sepenuhnya. Selain itu siswa merasa kesulitan memahami topik yang diberikan oleh guru. Apalagi ketika siswa dihadapkan pada sebuah topik yang tidak dikenalnya, siswa mengalami kesulitan dalam mengekspresikannya ke dalam tulisan, akibatnya siswa tidak dapat melanjutkan kegiatan menulis. Hal ini berakibat menulis narasi bahasa Jawa kurang menarik disebabkan oleh media yang digunakan guru kurang sesuai.

Dari latar belakang di atas maka peneliti mengambil judul "Penggunaan Flow Chart untuk Meningkatkan Keterampilan Menulis Narasi Siswa Kelas VIII SMP N 25 Purworejo" 
Latuheru (1988: 45) memberi batasan bagan atau chart sebagai serangkaian gambar atau uraian singkat yang tersusun rapi dan berbentuk lambang-lambang visual yang menunjukkan perbandingan, perbedaan, proses kerja dari awal sampai akhir suatu kejadian. Menurut Sadiman (1990: 37), "flow chart menggambarkan arus suatu masalah atau dapat pula menelusuri tanggung jawab atau hubungan kerja antara berbagai bagian atau seksi suatu organisasi". Pendapat yang lengkap dikemukakan oleh Soeparno (1988: 18) bahwa media flow chart adalah media yang berisi beberapa buah gambar yang berhubungan satu dengan yang lain sehingga membentuk serangkaian cerita. Biasanya setiap gambar diberi nomor urut sesuai dengan urut-urutan jalannya cerita.

Menulis diartikan sebagai kegiatan mengorganisasikan gagasan secara tematik serta mengungkapkannya secara tersurat (Akhadiah, 1995: 2). Adanya gagasan dalam menulis mengandung arti bahwa dalam menulis terdapat pesan yang disampaikan penulis kepada pembaca dalam bentuk karangan. Karangan merupakan ekspresi pikiran, gagasan, ide, pendapat dan pengalaman penulis disusun secara sistematis dan logis (Kurniawan, 1991: 4). Tarigan (1985: 21) mengatakan, menulis ialah menurunkan atau melukiskan lambang-lambang grafik yang menggambarkan suatu bahasa yang dipahami seseorang sehingga orang lain dapat membaca lambang-lambang grafik tersebut. Lambang- lambang grafik yang ditulis merupakan representasi bahasa tertentu sehingga memiliki makna tertentu pula yang dapat dipahami oleh orang lain (pembaca). Dari uraian di atas dapat dirangkum pengertian bahwa keterampilan menulis adalah kecakapan mengorganisasikan gagasan dalam bentuk bahasa tulis secara baik dan benar.

Karangan atau tulisan narasi adalah tulisan yang dibuat berdasarkan urutan waktu kejadian atau peristiwa. Agar tulisan narasi ini lebih menarik, biasanya penulis menceritakan sampai detail suatu peristiwa atau dengan memanipulasi urutan peristiwa. Keraf (1992: 136) mengungkapkan narasi adalah suatu bentuk wacana tentang sebuah peristiwa yang terjadi dalam suatu kesatuan waktu. Narasi juga dapat dirumuskan suatu bentuk wacana yang berusaha menggambarkan dengan sejelas-jelasnya kepada pembaca tentang suatu peristiwa yang telah terjadi.

\section{METODE PENELITIAN}

Metode penelitian yang dipergunakan adalah penelitian tindakan kelas atau classroom action research. Penelitian tindakan kelas adalah penelitian tentang kelas sasaran dengan memanfaatkan interaksi, partisipasi dan kolaborasi antara peneliti, guru bahasa Jawa, dan siswa sebagai subjek penelitian. Penelitian tindakan kelas merupakan salah satu strategi pemecahan masalah yang memanfaatkan tindakan nyata dalam proses pembelajaran di kelas. Tujuan dipilihnya jenis penelitian ini untuk meningkatkan keterampilan menulis narasi siswa kelas VIII SMP N 25 Purworejo dengan menggunakan media flow chart. Desain yang digunakan dalam penelitian ini adalah desain penelitian tindakan Kemmis dan Taggart.

\section{Subjek dan Objek Penelitian}

Subjek penelitian ini adalah siswa kelas 8B SMP Negeri 25 Purworejo. Sementara itu, objek penelitian tindakan kelas ini adalah keterampilan menulis narasi siswa kelas 8B SMP Negeri 25 Purworejo.

\section{Tempat dan Waktu Penelitian}

Penelitian ini dilakukan di SMPN 25 Purworejo yang terletak di Loano, Purworejo, Jawa Tengah. Pelaksanaan kegiatan observasi lapangan dilaksanakan pada bulan Juli. Penelitian tindakan ini dilakukan selama empat bulan dimulai dari awal agustus sampai desember. Tindakan dilakukan saat pelaksanaan kegiatan belajar mengajar bahasa Jawa berlangsung dengan frekuensi pembelajaran satu kali dalam satu minggu, dengan durasi waktu pembelajaran 80 menit setiap kali tatap muka.

\section{Teknik Pengumpulan Data}

Sumber data dalam penelitian tindakan ini meliputi siswa, guru, dokumen hasil pembelajaran dan proses pembelajaran. Adapun teknik pengumpulan data dilakukan dengan menggunakan observasi, catatan lapangan dan deskripsi pada saat pelaksanaan pembelajaran, serta tes. Semua teknik pengumpulan data tersebut dipergunakan untuk memperoleh data tentang hasil penelitian tindakan. Hasilnya kemudian dipadukan dan dianalisis untuk selanjutnya diambil kesimpulan dari hasil penelitian tersebut. 


\section{Instrumen Penelitian}

Instrumen merupakan alat yang dipergunakan untuk mengumpulkan data penelitian. Instrumen Penelitian ini adalah sebagai berikut:

1. Lembar Pengamatan digunakan untuk dapat mengungkapkan aktifitas siswa ketika proses pembelajaran menulis di kelas ketika tindakan dilaksanakan.

2. Catatan Lapangan yaitu mencatat persoalan-persoalan yang menarik. Catatan ini mencakup kesan dan penafsiran terhadap peristiwa yang terjadi di kelas ketika tindakan dilaksanakan.

3. Tes, digunakan untuk mengetahui keterampilan menulis narasi siswa. Tes yang dilakukan terdiri dari pretes dan postes. Pretes yaitu alat pengumpulan data yang akan menjabarkan kemampuan awal siswa, sedangkan postes merupakan alat pemeroleh data berupa kemampuan siswa setelah diberi tindakan pada akhir siklus.

\section{Teknik Analisis Data}

Teknik yang digunakan untuk menganalisis data dalam penelitian tindakan ini adalah deskriptif.

\section{Validitas Penelitian}

Dalam penelitian tindakan ini validitas yang digunakan adalah validitas demokrasi karena peneliti benar-benar berkolaborasi dengan guru maupun siswa, validitas proses dapat ditandai dengan ketepatan dalam proses penelitian dan validitas dialogis dapat ditunjukkan bahwa peneitian ini dilaksanakan dengan cara berdialog dengan guru dan kolaborator untuk mencari kritik dan saran.

\section{HASIL DAN PEMBAHASAN}

Pelajaran Bahasa Jawa hari Senin, tanggal 23 Juli 2007 di kelas VIII B pada saat prapenelitian

"Guru telah membuka pelajaran dengan cukup baik. Anak-anak cukup memperhatikan penjelasan guru. Pancingan-pancingan guru mendapat tanggapan baik dari beberapa siswa namun siswa-siswa lain banyak pula yang kelihatan belum paham terhadap dialog antara guru dan beberapa siswa yang aktif tersebut. Guru mengambil tindakan menerangkan secara detail materi yang sebagian besar siswa belum mengetahui tersebut, yaitu, ciri-ciri karangan narasi, deskripsi, eksposisi, argumentasi, serta persuasi. Guru sebenarnya sudah begitu detail dalam menerangkan. anak-anak memperhatikan secara serius penjelasan tersebut. Guru juga menerangkan contoh-contoh judul jenis-jenis karangan yang dimaksud. Setelah selesai menerangkan secara detail, guru memberi tugas kepada siswa untuk membuat karangan jenis narasi. Guru langsung menyuruh siswa menerapkan konsep karangan narasi untuk dipraktikkan menjadi sebuah karangan. Selama 40 menit, ternyata siswa-siswa masih banyak yang menyatakan pekerjaannya belum selesai. Guru mengakhiri pembelajaran dan mengumpulkan pekerjaan siswa."

Hasil pembelajaran menulis narasi para siswa kelas VIII B pada tahap prapenelitian menunjukkan nilai rata-rata kemampuan kelas masih sangat kurang. Hal ini berarti masih jauh dari yang diharapkan. Bentuk tulisan mereka rata-rata kurang. Namun demikian, kemampuan menulis yang seharusnya dimiliki oleh para siswa masih banyak yang belum seperti yang diharapkan. Misalnya, keruntutan dan kepaduan paragrafnya, keruntutan dan kepaduan kalimat, ketepatan penggunaan kalimat, kata, ejaan, serta tanda baca. Terkait dengan ini ditunjukkan pada hasil pretes siswa yang masih sangat kurang dan belum seperti yang diharapkan dapat dilihat dari rata-rata pencapaian skor karangan narasi siswa pada pretes, yaitu 56, 45 .

Setelah tindakan pada siklus ketiga ini dilakukan, dapat diidentifikasikan bahwa para siswa mengalami peningkatan keterampilan menulis karangan narasi seperti dikemukakan berikut:

1. Setelah mengikuti pembelajaran menulis karangan narasi dengan pendekatan proses dan media flow chart pada siklus ketiga, rata-rata skor hasil karangan narasi siswa mengalami peningkatan, yaitu dari ratarata skor 77,38 pada siklus kedua menjadi 81,65 pada siklus ketiga.

2. Setelah diberi tindakan pada siklus ketiga, dari 40 siswa yang mengikuti pembelajaran menulis karangan narasi dengan pendekatan proses, semua siswa mengalami peningkatan.

3. Persentase peningkatan pada siklus III 10,68\%.

4. Persentase peningkatan dari kemampuan awal ke siklus I 20, $58 \%$; ke siklus II 31, 75\%; dan ke siklus III 10, 68\%.

5. Pada siklus kedua, rata-rata skor karangan narasi siswa sebesar 77, 38 dengan skor terendah 70 dan skor tertinggi 82. Pada siklus ketiga, rata-rata skor karangan narasi siswa sebesar 81, 65 dengan skor terendah 71 dan skor tertinggi 85 . 
Seperti pada tabel berikut bahwa sebelum diberi tindakan rata-rata skor karangan narasi siswa 56,45 dengan skor terendah 34 dan skor tertinggi 70 . Setelah diberi tindakan, yaitu pada siklus pertama, rata-rata skor karangan narasi siswa adalah 64,68 dengan skor terendah 60 dan skor tertinggi 75 . Sementara itu, setelah diberi tindakan kedua, yaitu pada siklus kedua, ratarata skor karangan narasi adalah 77,38 dengan skor terendah 70 dan skor tertinggi sebesar 82. Dan setelah diberi tindakan ketiga, yaitu pada siklus ketiga, rata-rata skor karangan narasi adalah 81, 65 dengan skor terendah 71 dan skor tertinggi sebesar 85 .

Data-data tersebut mengandung makna bahwa keterampilan menulis karangan narasi siswa telah mengalami peningkatan yang cukup signifikan antara sebelum diberi tindakan dan sesudah diberi tindakan pertama, kedua, dan ketiga cukup memberikan peningkatan terhadap keterampilan menulis karangan narasi siswa. Dengan demikian, dapat dinyatakan bahwa penelitian tindakan ini telah mampu meningkatkan keterampilan menulis karangan narasi siswa.

Peningkatan skor keterampilan menulis karangan narasi siswa yang menjadi subjek peneliti ini cukup besar apabila dilihat dari rata-rata peningkatan skor sebelum diberi tindakan, setelah diberi tindakan pada siklus pertama, kedua dan ketiga. Dari kondisi sebelum pemberian tindakan ke kondisi pemberian tindakan pada siklus pertama dapat dilihat adanya peningkatan skor, yaitu dari (rata-rata) 56,45 menjadi (rata-rata) 64, 68. Dari kondisi pemberian tindakan pada siklus pertama ke kondisi pemberian tindakan pada siklus kedua dapat dilihat adanya peningkatan skor, yaitu dari 64, 68 menjadi 77, 38. Dari kondisi pemberian tindakan pada siklus kedua ke kondisi pemberian tindakan pada siklus ketiga dapat dilihat adanya peningkatan skor, yaitu dari 77, 38 menjadi 81, 65. Dengan demikian dapat diketahui bahwa dari kondisi sebelum pemberian tindakan ke kondisi setelah pemberian tindakan pada siklus pertama terjadi peningkatan sebesar 8, 23 dari kondisi setelah pemberian tindakan pada sikus kedua terjadi peningkatan sebesar 12, 70. Dan dari kondisi setelah pemberian tindakan pada siklus ketiga terjadi peningkatan sebesar 4, 27. Untuk lebih jelasnya dapat dilihat pada tabel berikut.
Tabel 1. Daftar Skor Narasi Siswa Pretes, postes I, postes 2 dan postes 3

\begin{tabular}{|c|c|c|c|c|}
\hline No & Pretes & $\begin{array}{l}\text { Posttes } \\
\text { Siklus I }\end{array}$ & $\begin{array}{l}\text { Posttes } \\
\text { Siklus II }\end{array}$ & $\begin{array}{l}\text { Posttes } \\
\text { Siklus III }\end{array}$ \\
\hline 1 & 56 & 62 & 75 & 79 \\
\hline 2 & 57 & 62 & 75 & 77 \\
\hline 3 & 66 & 70 & 77 & 78 \\
\hline 4 & 70 & 77 & 82 & 85 \\
\hline 5 & 34 & 53 & 75 & 78 \\
\hline 6 & 36 & 60 & 71 & 79 \\
\hline 7 & 73 & 75 & 78 & 80 \\
\hline 8 & 68 & 70 & 77 & 80 \\
\hline 9 & 57 & 62 & 79 & 80 \\
\hline 10 & 67 & 69 & 78 & 79 \\
\hline 11 & 54 & 63 & 75 & 78 \\
\hline 12 & 56 & 65 & 70 & 71 \\
\hline 13 & 55 & 62 & 78 & 82 \\
\hline 14 & 57 & 64 & 79 & 80 \\
\hline 15 & 54 & 60 & 79 & 82 \\
\hline 16 & 35 & 60 & 78 & 79 \\
\hline 17 & 65 & 67 & 75 & 80 \\
\hline 18 & 66 & 71 & 81 & 82 \\
\hline 19 & 65 & 66 & 77 & 78 \\
\hline 20 & 68 & 70 & 81 & 83 \\
\hline 21 & 68 & 69 & 78 & 79 \\
\hline 22 & 65 & 67 & 75 & 78 \\
\hline 23 & 58 & 63 & 78 & 79 \\
\hline 24 & 64 & 65 & 79 & 81 \\
\hline 25 & 36 & 60 & 76 & 79 \\
\hline 26 & 37 & 62 & 78 & 82 \\
\hline 27 & 58 & 62 & 79 & 80 \\
\hline 28 & 56 & 63 & 76 & 81 \\
\hline 29 & 65 & 70 & 81 & 82 \\
\hline 30 & 57 & 62 & 78 & 79 \\
\hline 31 & 56 & 62 & 71 & 75 \\
\hline 32 & 57 & 62 & 80 & 83 \\
\hline 33 & 34 & 63 & 79 & 80 \\
\hline 34 & 56 & 64 & 77 & 79 \\
\hline 35 & 55 & 63 & 78 & 79 \\
\hline 36 & 54 & 62 & 79 & 80 \\
\hline 37 & 37 & 62 & 78 & 81 \\
\hline 38 & 55 & 62 & 78 & 80 \\
\hline 39 & 65 & 66 & 76 & 77 \\
\hline 40 & 66 & 70 & 81 & 83 \\
\hline Rerata & 56,45 & 64,68 & 77,38 & 81,65 \\
\hline
\end{tabular}

\section{HASIL DAN PEMBAHASAN}

Hasil pelaksanaan penelitian berdasarkan perencanaan, tindakan dan observasi, refleksi tiap-tiap siklus.

\section{Proses Tindakan}

Proses tindakan merupakan proses pelaksanaan tindakan pembelajaran menulis narasi dengan menggunakan media flow chart. Proses tindakan disajikan dalam bentuk proses pembelajaran menulis narasi menggunakan pendekatan proses dan media flow chart. Pelaksanaan tindakan dilakukan dalam tiga 
siklus, yang memerlukan waktu 15 kali pertemuan. Subjek penelitian, yaitu siswa kelas 8B SMPN 25 Purworejo yang berjumlah 40 siswa.

Penelitian tindakan ini terbagi dalam 3 siklus, yaitu siklus I, siklus II dan siklus III. Setiap proses pembelajaran menulis narasi selalu diterapkan pendekatan proses dan penggunaan media flow chart. Pembelajaran menulis narasi diawali dengan pretes. Pretest dilaksanakan untuk mengetahui kondisi awal kemampuan siswa dalam menulis narasi. Pemberian tindakan dilakukan selama 5 kali dalam setiap siklus. Setiap siklus diakhiri dengan tes. Hal itu, dilakukan untuk mengetahui peningkatan keterampilan menulis narasi siswa setelah menggunakan media flow chart. Siklus pertama lima kali pertemuan diberi perlakuan dengan menerapkan pendekatan proses dan menggunakan media flow chart tentang kegiatan siswa setelah bangun tidur, sedangkan siklus kedua sebanyak lima kali perlakuan dengan menerapkan pendekatan proses dan menggunakan media flow chart tentang kegiatan berkemah dan siklus ketiga sebanyak lima kali perlakuan dengan menerapkan pendekatan proses dan menggunakan media flow chart tentang menabung. Langkah-langkah pembelajaran yang telah ditetapkan dalam perencanaan yaitu pendahuluan, pramenulis, menulis kerangka karangan, merevisi, menyunting, mempublikasi. Siswa telah melakukan kegiatan sebanyak lima kali melalui proses pramenulis, menulis kerangka karangan, merevisi, menyunting dan mempublikasi (dibaca di depan kelas). Para siswa menampakkan keantusiasan dalam pembelajaran menulis dengan pendekatan proses. Meskipun demikian, tampak pula bahwa para siswa mengalami berbagai masalah. Masalah-masalah tersebut antara lain tampak ketika mereka memulai menulis karangan, mereka mengalami kesulitan dalam menentukan judul, membuat kerangka karangan, serta mengembangkannya. Untuk itu, kolaborator selalu menjelaskan dan memberikan bimbingan kepada siswa dalam menulis karangan narasi. Kolaborator juga melibatkan teman sekelasnya dalam mengatasi berbagai kesulitan dalam menulis tersebut. Selain itu, mereka juga mengalami kesulitan dalam mengikuti diskusi tentang pembahasan pendekatan proses dan penerapannya dalam pembelajaran menulis. Dalam mengikuti diskusi, sebagian besar siswa bersikap pasif dan hanya beberapa siswa yang bersikap aktif. Sikap pasif tersebut, tampaknya disebabkan oleh belum dipahaminya konsep pembelajaran menulis dengan pendekatan proses dan belum terbiasanya mereka dalam melakukan diskusi. Permasalahan-permasalahan tersebut dapat diatasi setelah kolaborator memberikan penjelasan tentang pendekatan proses dan memberikan motivasi dan arahan bahwa diskusi dan hasilnya sangat menentukan keberhasilan mereka dalam menulis. Tindakan tersebut ternyata dapat memberikan hasil yang cukup baik. Para siswa akhirnya menyadari pentingnya bertukar pikiran dan pengalaman dalam proses penulisan sebuah karangan.

Praktik menulis karangan narasi dengan pendekatan proses dan media flow chart juga dapat diikuti dengan baik oleh siswa. Setelah dilakukan tindakan pada siklus pertama, walaupun belum maksimal, hasilnya menunjukkan bahwa keterampilan siswa dalam menulis karangan narasi mengalami peningkatan, setelah diberi tindakan pada siklus pertama, nilai rata-rata hasil karangan narasi siswa mengalami peningkatan. Hal itu dapat dilihat dari rata-rata pencapaian skor karangan narasi mereka, yaitu dari 56, 45 sebelum siklus pertama menjadi 64, 68 setelah tindakan pada siklus pertama.

Pada pelaksanaan siklus II langkah tindakan yang dilakukan sesuai dengan rancangan yang telah disusun. Namun, siswa masih memiliki kesulitan dalam merevisi dan menyunting tulisan. Oleh karena itu, kolaborator sangat berperan dalam membantu siswa untuk merevisi isi tulisan dan menyunting aspek tulisan. Tindakan yang dilakukan telah menghasilkan perubahan yang positif dalam hal keterampilan menulis siswa dan sikap siswa terhadap pembelajaran menulis. Terdapat dampak positif yang tidak direncanakan yaitu pada saat pembelajaran menulis dilakukan siswa sering membaca dan berbicara secara langsung dengan teman atau guru untuk bertanya atau menyampaikan pendapatnya.

Pada pelaksanaan siklus III pada umumnya siswa telah dapat mengikuti pembelajaran menulis dengan pendekatan proses dan media flow chart yang dilakukan 
guru sesuai dengan rancangan tindakan yang telah disusun. Siswa sudah dapat merevisi dan menyunting tulisan lebih baik. Tindakan yang dilakukan telah menghasilkan perubahan yang positif dalam hal keterampilan menulis siswa dan sikap siswa terhadap pembelajaran menulis. Siswa tampak tidak merasa terpaksa mengikuti pembelajaran menulis sehingga menimbulkan perasaan senang terhadapnya. Terdapat dampak positif yang tidak direncanakan yaitu pada saat pembelajaran menulis dilakukan siswa sering membaca dan berbicara secara langsung dengan teman atau guru untuk bertanya atau menyampaikan pendapatnya. Kolaborator dan siswa tidak merasa waktunya tersita untuk penelitian tindakan ini.

\section{Peningkatan Keterampilan Menulis Narasi Siswa dengan Media Flow Chart}

Penggunaan media flow chart dalam penulisan narasi siswa ternyata mampu menjadi stimulus yang kuat bagi siswa untuk meningkatkan keterampilan menulisnya pada tindakan selanjutnya. Artinya rendahnya kemampuan menulis narasi siswa sebenarnya masih dapat ditingkatkan dengan cara memberi rangsangan berupa media yang tepat. Pemberian media flow chart sebagai rangsangan untuk meningkatkan penulisan narasi siswa ternyata cukup berarti. Siswa yang semula sulit menuangkan ide atau gagasannya ke dalam bentuk tulisan akhirnya mampu dengan lancar menuangkan idenya.

Keberhasilan siswa dari siklus ke siklus yang merupakan hasil dari penelitian tindakan kelas ini dapat diketahui melalui ada tidaknya peningkatan hasil akhir dan aspek-aspek yang ada dalam tulisan narasi siswa. Setiap kali penulisan narasi, dalam penelitian tindakan kelas ini dilakukan evaluasi dan refleksi baik sebelum maupun sesudah implementasi tindakan. Siklus pertama dimulai setelah refleksi awal tentang perlunya dilakukan tindakan berupa penggunaan media flow chart dalam penulisan narasi siswa. Refleksi awal dihasilkan dari evaluasi terhadap penulisan narasi sebelum implementasi tindakan.

Pada akhir tindakan dalam setiap siklus, peneliti juga melakukan refleksi. Pelaksanaan tindakan pada siklus I (narasi 2) menghasilkan peningkatan skor hasil keterampilan menulis. Tetapi peningkatan skor tersebut tidak diikuti oleh peningkatan kategori tulisan narasi dari sedang-cukup ke kategori cukup baik.
Berdasarkan peningkatan skor, pengamatan dan catatan lapangan, peningkatan keterampilan menulis narasi siswa yang kurang tinggi karena saat itu mereka baru pertama kali memanfaatkan media flow chart dalam penulisan narasi. Selain itu, pelaksanaan pendekatan proses dalam penulisan narasi yang baru pertama kali mereka kenal dalam pembelajaran menulis. Selama ini siswa melakukan kegiatan menulis dengan pendekatan tradisional, yang berorientasi pada hasil saja. Artinya mereka belum mengetahui lebih banyak tentang fungsi dari setiap tahap yang terdapat dalam pendekatan proses seperti pramenulis, menulis draf kasar, merevisi, menyunting, dan mempublikasikan. Dalam kegiatan merevisi dan menyunting, hubungan interaksi antar siswa seperti diskusi, masih kurang sehingga mereka tidak menyadari banyaknya kesalahan aspek-aspek menulis yang terjadi dalam tulisan narasi mereka. Dari uraian ini dapat diketahui bahwa implementasi tindakan pada siklus I dipandang kurang berhasil.

Berdasarkan refleksi di atas, maka perlu dilakukan perencanaan ulang (replannning) untuk siklus selanjutnya. Untuk mengatasi kelemahan dalam implementasi tindakan pada siklus, maka perlu dilakukan usaha pendekatan kepada siswa misalnya berdiskusi tentang masalah yang ada dalam menulis narasi. Guru dapat berkeliling memonitor kesulitan siswa dalam memanfaatkan media flow chart. Untuk merevisi tindakan yang berkaitan dengan pelaksanaan pendekatan proses, guru sebaiknya membagi siswa dalam kelompok-kelompok diskusi. Setiap kelompok terdiri dari empat orang siswa, dan setiap siswa harus mendiskusikan draf kasar yang telah dibuatnya agar mereka memperoleh masukan dari teman dan guru bila perlu, untuk revisi isi maupun penyuntingan. Setelah dilakukan evaluasi dan refleksi pada akhir siklus I, langkah selanjutnya adalah menyusun rencana ulang untuk tindakan siklus II.

Berdasarkan data-data yang diperoleh dari hasil pengamatan dan pemantauan selama proses pembelajaran menulis berlangsung, dapat diketahui bahwa pembelajaraan dengan melibatkan siswa secara aktif dan langsung dalam proses menulis dan melalui tahapantahapan yang ada dalam pendekatan proses, siswa merasa lebih senang dan lebih tenang dalam menulis. Hal ini terjadi karena dalam 
setiap tahap proses penyusunan atau pembuatan karangan narasi, mereka dapat bertukar pikiran dengan teman lain ataupun dengan guru. selain itu, dalam menyelesaikan karangannya, mereka juga tidak harus tergesagesa. Hal ini jarang terjadi dalam proses pembelajaran menulis dengan pendekatan tradisional yang selama ini mereka ikuti dalam proses pembelajaran menulis. Dengan pendekatan proses dan media flow chart dalam menulis ini terbukti dapat meningkatkan keterampilan siswa dalam menulis karangan narasi.

Setelah dilakukan evaluasi dan refleksi pada akhir siklus II, langkah selanjutnya adalah menyusun rencana ulang untuk tindakan siklus III. Sebelum diberi tindakan rata-rata skor karangan narasi siswa 56,45 dengan skor terendah 34 dan skor tertinggi 70 . Setelah diberi tindakan, yaitu pada siklus pertama, rata-rata skor karangan narasi siswa adalah 64,68 dengan skor terendah 60 dan skor tertinggi 75 . Sementara itu, setelah diberi tindakan kedua, yaitu pada siklus kedua, ratarata skor karangan narasi adalah 77, 38 dengan skor terendah 70 dan skor tertinggi sebesar 82 . Dan setelah diberi tindakan ketiga, yaitu pada siklus ketiga, rata-rata skor karangan narasi adalah 81, 65 dengan skor terendah 71 dan skor tertinggi sebesar 85 .

Data-data tersebut mengandung makna bahwa keterampilan menulis karangan narasi siswa telah mengalami peningkatan yang cukup signifikan antara sebelum diberi tindakan dan sesudah diberi tindakan pertama, kedua, dan ketiga cukup memberikan peningkatan terhadap keterampilan menulis karangan narasi siswa. Dengan demikian, dapat dinyatakan bahwa penelitian tindakan ini telah mampu meningkatkan keterampilan menulis karangan narasi siswa.

Peningkatan skor keterampilan menulis karangan narasi siswa yang menjadi subjek peneliti ini cukup besar apabila dilihat dari rata-rata peningkatan skor sebelum diberi tindakan, setelah diberi tindakan pada siklus pertama, kedua dan ketiga. Dari kondisi sebelum pemberian tindakan ke kondisi pemberian tindakan pada siklus pertama dapat dilihat adanya peningkatan skor, yaitu dari (rata-rata) 56,45 menjadi (rata-rata) 64, 68. Dari kondisi pemberian tindakan pada siklus pertama ke kondisi pemberian tindakan pada siklus kedua dapat dilihat adanya peningkatan skor, yaitu dari 64, 68 menjadi 77, 38. Dari kondisi pemberian tindakan pada siklus kedua ke kondisi pemberian tindakan pada siklus ketiga dapat dilihat adanya peningkatan skor, yaitu dari 77, 38 menjadi 81, 65. Dengan demikian dapat diketahui bahwa dari kondisi sebelum pemberian tindakan ke kondisi setelah pemberian tindakan pada siklus pertama terjadi peningkatan sebesar 8, 23 dari kondisi setelah pemberian tindakan pada sikus kedua terjadi peningkatan sebesar 12,70. Dan dari kondisi setelah pemberian tindakan pada siklus ketiga terjadi peningkatan sebesar 4, 27.

Berdasarkan hasil keterampilan menulis narasi siswa pada bagian sebelumnya, dapat diketahui bahwa keterampilan menulis narasi siswa meningkat setelah diberikan tindakan pembelajaran yang menggunakan media flow chart. Hal ini membuktikan bahwa tindakan yang dilakukan cukup berhasil. Pembelajaran kebahasaan, khususnya dalam peningkatan keterampilan menulis narasi menuntut guru untuk mampu memilih dan menentukan pendekatan dan media yang tepat dalam mengajar. Penerapan suatu pendekatan dan media yang tepat dalam kegiatan belajar mengajar diharapkan dapat meningkatkan keterampilan menulis narasi siswa.

Dari hasil observasi dengan guru Bahasa Jawa kelas 8 B SMP N 25 Purworejo, ternyata beliau mengalami kesulitan dalam melaksanakan pembelajaran bahasa Jawa khususnya keterampilan menulis narasi. Selama ini, guru masih menerapkan pendekatan tradisional dalam proses menulis narasi, di mana guru lebih menitikberatkan pada penyampaian materi teoritik daripada praktik menulis. Akibatnya, siswa tidak mempunyai pengalaman yang cukup dalam menulis. Selain hal itu, siswa cenderung kurang berminat dalam mengikuti kegiatan menulis.

Berdasarkan pemantauan kegiatan siklus I sampai kegiatan siklus III dapat dilihat adanya peningkatan keterampilan menulis narasi siswa dengan menggunakan media flow chart. Peningkatan tersebut dapat dilihat dari segi skor maupun dari segi keterampilan siswa dalam menulis narasi. Dari ketiga siklus yang dilaksanakan dalam penelitian ini, masingmasing siklus memiliki fokus dan bentuk tindakan yang berbeda. pada siklus I yang merupakan tahap pengenalan terhadap pembelajaran menulis narasi dengan media flow chart, siswa dibagi dalam bentuk 
kelompok. Meskipun siswa terbagi dalam bentuk kelompok, siswa tetap melakukan kegiatan menulis secara individu. Kerja kelompok hanya dilakukan pada saat merevisi serta mengedit kesalahan tulisan. Untuk kegiatan pramenulis yang terdiri dari pengamatan terhadap media dan penyusunan ide tulisan dilakukan di dalam kelas. Fokus permasalahan yang akan diatasi adalah permasalahan yang dikemukakan guru pada saat prasurvei. Meskipun hasil tulisan siswa di siklus I belum optimal, namun siswa sudah mengalami sedikit peningkatan. Di samping itu, siswa yang menjadi subjek dalam penelitian ini mulai mengerti dan memahami tentang pembelajaran menulis narasi dengan media flow chart.

Pada siklus II siswa tidak lagi terbagi dalam kelompok melainkan bekerja secara individu. Kegiatan pramenulis tetap dilakukan di ruangan kelas. Fokus permasalahan yang ada pada pelaksanaan siklus sebelumnya. Dari hasil tulisan siswa di siklus I dapat diketahui aspek isi gagasan yang merupakan indikator dasar dari tulisan narasi yang terdiri dari alur, tokoh, perbuatan. Aspek menulis yang lain juga belum menunjukkkan peningkatan yang cukup berarti. Melalui kegiatan siklus II dapat diketahui tulisan siswa mengalami kemajuan yang berarti. Namun demikian, unsur penceritaan yang merupakan indikator dasar dari tulisan narasi masih belum tercipta dengan baik.

Pada siklus III siswa tidak lagi terbagi dalam kelompok melainkan bekerja secara individu. Kegiatan pramenulis tetap dilakukan di ruangan kelas. Fokus permasalahan yang ada pada pelaksanaan siklus sebelumnya. Dari hasil tulisan siswa di siklus II dapat diketahui aspek isi gagasan yang merupakan indikator dasar dari tulisan narasi yang terdiri dari alur, tokoh, perbuatan. Aspek menulis yang lain sudah menunjukkan peningkatan yang cukup berarti. Melalui kegiatan siklus III ini dapat diketahui tulisan siswa mengalami kemajuan yang berarti. Unsur penceritaan yang merupakan indikator dasar dari tulisan narasi telah tercipta dengan baik.

Secara keseluruhan, pelaksanaan penelitian tindakan kelas ini telah berhasil meningkatkan keterampilan siswa dalam menulis narasi. Hal ini ditandai dengan adanya peningkatan skor, baik pada akhir tindakan kegiatan siklus I maupun di akhir tindakan kegiatan siklus III. Disamping itu, siswa tidak lagi mengalami kesulitan untuk menulis narasi dan siswa mengakui bahwa penggunaan media flow chart dapat melatih mereka untuk dapat menulis narasi dengan baik.

Pelaksanaan penelitian tindakan kelas ini juga memberikan manfaat bagi guru khususnya guru bahasa Jawa kelas 8 B SMP N 25 Purworejo yang bertindak sebagai kolaborator. Guru mengakui bahwa penelitian tindakan kelas ini mampu meningkatkan skor menulis narasi anak didiknya. Pengalaman yang diperoleh selama melaksanakan penelitian ini juga dapat beliau bagikan pada sesama guru sehingga diharapkan dapat meningkatkan mutu pengetahuan dan keterampilan pengelolaan pembelajaran menulis sebagai salah satu aspek pelajaran bahasa Jawa.

\section{SIMPULAN DAN SARAN Simpulan}

Sesuai dengan permasalahan dan hasil penelitian serta pembahasan dalam Penelitian Tindakan Kelas ini, dapat disimpulkan bahwa tindakan berupa penggunaan media flow chart mampu meningkatkan keterampilan menulis narasi siswa. Pelaksanaan tindakan selama tiga siklus dapat meningkatkan skor menulis narasi. Media flow chart dapat membantu siswa menuangkan ide atau gagasannya dengan lancar. Selanjutnya hasil penelitian secara rinci dapat disampaikan sebagai berikut:

1. Dari empat puluh siswa yang mengikuti praktik mengarang narasi dengan pendekatan proses dan media flow chart, 40 siswa mengalami kenaikan skor.

2. Sebelum diberi tindakan kemampuan menulis siswa sangat kurang dengan ratarata skor karangan narasi siswa 56,45 dengan skor terendah 34 dan skor tertinggi 70. Setelah diberi tindakan, yaitu pada siklus pertama, kemampuan menulis siswa cukup meningkat dengan rata-rata skor karangan narasi siswa adalah 64,68 dengan skor terendah 60 dan skor tertinggi 75 . Sementara itu, setelah diberi tindakan kedua, yaitu pada siklus kedua, kemampuan menulis siswa lebih meningkat dengan rata-rata skor karangan narasi adalah 77, 38 dengan skor terendah 70 dan skor tertinggi sebesar 82. Dan setelah diberi tindakan ketiga, yaitu pada siklus ketiga, kemampuan menulis siswa meningkat lagi dengan rata-rata skor karangan narasi adalah 81, 65 dengan skor terendah 71 dan skor tertinggi sebesar 85 . 


\section{Saran}

Saran-saran yang dapat disampaikan di sini adalah sebagai berikut:

1. Siswa disarankan mempublikasikan hasil karyanya ke dalam bentuk majalah dinding yang ada di sekolah.

2. Penelitian Tindakan Kelas ini hendaknya terus dibudayakan oleh guru agar keterampilan menulis siswa semakin meningkat.

\section{DAFTAR PUSTAKA}

Akhadiah, Sabarti. 1995. Pembinaan Kemampuan Menulis Berbahasa Indonesia. Jakarta: Erlangga.

Dwipawati. 2000. Efektivitas Penggunaan Media Gambar Berseri dalam Meningkatkan Kemampuan Menulis Siswa Kelas V SD Tukangan, Yogyakarta. Yogyakarta: FBS UNY.

Enre, Fachrudin Ambo. 1988. Dasar-dasar Keterampilan Menulis. Jakarta: Depdikbud Dirjen Proyek Pengembangan Lembaga Pendidikan Tenaga Kependidikan.

Hamalik, Oemar. 1986. Media Pendidikan. Bandung: Alumni.

Keraf, Gorys. 1980. Terampil Berbahasa Indonesia I. Jakarta: Balai Pustaka. 1993. Komposisi. Ende: Nusa Indah.

Kurniawan, Khaerudin. 1991. Kemampuan Tulis Mahasiswa Jurusan Pendidikan Bahasa dan Sastra Indonesia dalam Rangka Meningkatkan Mutu Perkuliahan Ekspresi Tulis. Yogyakarta: FPBS IKIP Yogyakarta.

Latuheru. 1988. Media Pembelajaran dalam Proses Belajar-Mengajar Masa Kini. Jakarta: Depdikbud Dirjen Perguruan Tinggi Proyek Pengembangan Lembaga Pendidikan Tenaga Kependidikan.

Loka, Caraka. 1971. Tehnik Mengarang. Jakarta: Kanisius.

Madya, S. 1994. Panduan Penelitian Tindakan. Yogyakarta: Lembaga Penelitian IKIP Yogyakarta.
Marini. 2000. Keefektifan Pendekatan Proses dalam Pengajaran Menulis di Kelas I SLTPN 2 Pajangan. Skripsi. FBS UNY.

Ramlan. 1993. Paragraf, Alur Pikir dan Kepaduannya dalam Bahasa Indonesia. Yogyakarta: Andi Offset.

. 1987. Morfologi Suatu Tinjauan Deskriptif. Yogyakarta: Karyono.

Rumampuk. 1988. Media Instruksional IPS. Jakarta: Depdikbud Dirjen Perguruan Tinggi Proyek Pengembangan Lembaga Pendidikan Tenaga Kependidikan.

Sadiman, Arief. S. 1986. Media Pendidikan, Pengertian, Pengembangan, dan Pemanfaatan. Jakarta: PT. Rajawali.

Soeparno. 1988. Media Pengajaran Bahasa. Yogyakarta: IKIP Yogyakarta.

Sujana dan Rivai. 1992. Media Pengajaran. Bandung: Sinar Baru.

Suleiman. 1985. Media Audio-visual untuk Pengajaran, Penerangan dan Penyuluhan. Jakarta: PT. Gramedia.

Supadi, Imam. 1987. Efektifitas Penggunaan Media Pengajaran dalam Hubungan dengan Prestasi Belajar Siswa di Sekolah. Yogyakarta: FIP IKIP Yogyakarta.

Tarigan, Henry Guntur. 1985. Menulis Sebagai Suatu Keterampilan Berbahasa. Bandung: Angkasa.

Tim Bahasa dan Sastra Indonesia SMA. 2005. Bahasa dan Sastra Indonesia 1 untuk SMA Kelas X. Jakarta: Galaxy Puspa Mega.

Raharjo, Toto. 1994. Kontribusi Kemampuan Struktur Gramatikal Bahasa Indonesia terhadap Keterampilan Menulis Siswa Kelas II SMAN Comal Tahun Ajaran 1993/ 1994. Skripsi. FBS IKIP Yogyakarta.

Zuchdi, D. 1996. Pembelajaran Menulis dengan Pendekatan Proses. Pidato Ilmiah pada sidang Senat FPBS IKIP Yogyakrta tanggal 15 November 1996. 